\title{
HUB UNGAN KOMUNIKASI KEPALA RUANGAN TERHADAP MOTIVASI KERJA DAN KINERJA PERAWAT PELAKSANA DI RUMAH SAKIT HERMINA JATINEGARA 2018
}

\author{
Ns.Junita Maratur Silitonga, M.Kep ${ }^{1}$, Ns.Retno Winarti, M.Kep.,Sp.Kep.Mat ${ }^{2}$ \\ 1. Akademi Keperawatan Manggala Husada, Jakarta 13930, Indonesia \\ 2. Akademi Keperawatan Manggala Husada, Jakarta 13930, Indonesia
}

Email: junitasilitonga1969@gmail.com

\begin{abstract}
ABSTRAK
Komunikasi kepala ruangan dan motivasi perawat merupakan faktor yang dapat mempengaruhi kinerja perawat. Penelitian ini bertujuan untuk mengetahui hubungan komunikasi kepala ruangan dan motivasi perawat dengan kinerja perawat pelaksana di rumah sakit hermina jatinegara. Desain penelitian menggunakan pendekatan cross sectional. Jumlah sampel dalam penelitian ini 149 responden. Analisis yang digunakan adalah analisis univariat, bivariate. Pada hasil analisis bivariat terdapat hubungan komunikasi kepala ruangan dan motivasi perawat dengan kinerja perawat pelaksana di Rumah Sakit Hermina Jatinegara. Diharapkan institusi rumah sakit dapat lebih optimal melakukan supervisi terhadap motivasi perawat dan komunikasi kepala ruangan

Kata Kunci: Komunikasi kepala ruangan, motivasi, dan kinerja perawat

ABSTRACT

the communication room head nurse and motivation is a factor that can affect the performance of the nurses. This research aims to know the communication link and motivation's head nurse with the performance of the implementing nurse in hospital herminajatinegara. Design research using the approach of cross sectional. The number of samples in this research 149 respondents. Analysis of univariate analysis is used, the bivariate. On the results of the analysis of the communication link there Chief bivariat and motivation of nurses with the performance of the implementing nurse in hospital Hermina Jatinegara.It is hoped the institution of hospitals can be more optimal supervision towards motivation and communication room head nurse
\end{abstract}

Keywords: head of Communication, motivation, and performance of nurses

\section{A. PENDAHULUAN}

Komunikasi yang terputus akan memberikan dampak pada buruknya hubungan antar individu atau kelompok. Tatanan klinik seperti rumah sakit yang dinyatakan sebagai salah satu sistem dari kelompok sosial mempunyai kepentingan yang tinggi pada unsur komunikasi. Komunikasi di lingkungan rumah sakit diyakini sebagai modal utama untuk meningkatkan kualitas pelayanan yang akan ditawarkan kepada konsumennya. Keperawatan sangat berhubungan dengan komunikasi. komunikasi merupakan proses kompleks yang melibatkan perilaku dan memungkinkan individu untuk berhubungan dengan orang lain dan dunia sekitarnya. Maka komunikasi sangat penting bagi perawat (Mundakir, 2006)
Komunikasi merupakan pemberian umpan balik sebagai informasi dan sebagai penguatan (reinforcement). Media komunikasi dipergunakan untuk mengenal perawat - perawat, dengan demikian akan memperbaiki harga diri mereka, dan untuk menjelaskan prilaku yang diharapkan dan meningkatkan prestasi kerja mereka (Swansburg, 2000).

Kepala ruangan merupakan jabatan yang bertanggung jawab untuk melakukan pelaporan atas kinerjanya pada manajemen keperawatan. Tugas utama kepala ruangan yaitu melakukan pengawasan atas jabatan yang ada dibawahnya, serta mengkoordinasikan kepada bawahan atas segala kebijakan yang berlaku di rumah 
sakit. Kepala ruangan mempunyai tugas melakukan pengaturan pada jabatan bekerja sesuai dengan aturan yang berlaku sebagai manajer keperawatan di ruangan (Swansburg, 2000).

Pencapaian hasil kinerja dapat dilihat dari prestasi kerja, tanggung jawab, ketaatan, kejujuran, dan kerjasama (Sudarmanto, 2009). Demikian halnya kinerja perawat, tingkat pencapain yang telah dilakukan pada saat memberikan pelayanan keperawatan dapat dinilai dari prestasi kerja, tanggung jawab, ketaatan, kejujuran dan kerjasama yang ditunjukkan oleh perawat. Penilaian kinerja perawat merupakan suatu proses untuk mengetahui secara kuantitas dan kualitas pencapaian hasil kerja perawat yang ditunjukkan dari penerapan pengetahuan, ketrampilan, dan pertimbangan afektif dalam pemberian pelayanan keperawatan. Pencapaian kinerja yang optimal dari perawat merupakan harapan yang mesti terwujud demi peningkatan kualitas layanan kesehatan dalam suatu institusi pelayanan kesehatan. Hal ini tidak terlepas dari peran manajer keperawatan dalam menjalankan proses kepemimpinan dan fungsi - fungsi manajemen.

Berdasarkan dari studi pendahuluan yang dilakukan oleh peneliti pada awal bulan Januari 2016, dari hasil wawancara yang telah dilakukan dengan kepala ruangan dan manajer keperawatan terkait dengan fungsi manajemen yang dilaksanakan di rumah sakit masih kurang optimal, perawat pelaksana belum dilibatkan dalam perencanaan ruangan, pembagian tugas masih berupa instruksi yang bersifat sementara, pengawasan yang dilakukan oleh manajer keperawatan masih bersifat temporer jika ada masalah. Hal ini menunjukkan belum adanya landasan yang kuat untuk menggerakan organisasi. Oleh karena itu untuk meningkatkan produktifitas kerja, keberhasilan dan kepuasan kerja perawat sangat dipengaruhi oleh adanya motivasi, komunikasi dan kinerja kepala ruangan dalam membangkitkan antusiasme dari perawat pelaksana dalam memberikan pelayanan yang bermutu.
Berdasarkan hasil wawancara perawat merasa tidak puas dengan jenjang karir dan kesempatan pengembangan kompetensi. Hal ini tentunya dapat menurunkan motivasi dari perawat yang akhirnya akan berdampak pada penurunan kepuasan perawat, perawat menyatakan kurang puas dengan efektifitas tim yang bekerja dalam ruang rawat inap serta perawat merasa tidak puas dengan kegiatan supervisi di ruangan.

\section{B. Metodologi Penelitian}

Berdasarkan tujuan penelitian, desain penelitian ini menggunakan deskriptif analitik dengan pendekatan cross sectional study (Notoadmodjo, 2009). Penelitian ini merupakan penelitian yang dirancang untuk menentukan hubungan variabel yang berbeda dalam satu populasi. Penelitian ini bertujuan untuk melihat pengaruh komunikasi, motivasi dan sistem penghargaan terhadap kepuasan kerja dan dampaknya pada kinerja perawat pelaksana di RS Hermina Jatinegara.

\section{Hasil dan Pembahasan}

1. Hubungan antara komunikasi kepala ruangan dengan kinerja perawat di RS.Hermina Jatinegara

Hasil penelitian ini membuktikan bahwa ada hubungan antara komunikasi kepala ruangan dengan kinerja perawat di RS.Hermina Jatinegara. Menurut Stuart G.W dalam Ibadurokhman (2007) menyatakan bahwa komunikasi terapeutik merupakan hubungan interpersonal antara perawat dan klien, dalam hubungan ini perawat dan klien memperoleh pengalaman belajar bersama dalam rangka memperbaiki pengalaman emosional klien.Penelitian ini didukung oleh penelitian yang dilakukan Hermawan (2011) melakukan penelitian tentang hubungan komunikasi terapeutik terhadap kinerja perawat di rawat jalan RSUD Kabupaten Bekasi menunjukan bahwa ada hubungan yang signifikan antara komunikasi terapeutik dengan kinerja perawat dirawat jalan. Menurut analisis peneliti memang ada keterkaitan antara komunikasi terapeutik dengan kinerja perawat, 
semakin baik komunikasi terapeutik maka semakin baik pula kinerja perawat.

2. Hubungan motivasi dengan kinerja perawat di RS.Hermina Jatinegara

Hasil penelitian ini membuktikan bahwa ada hubungan antara motivasi perawat dengan kinerja perawat di RS.Hermina Jatinegara. Penelitian ini didukung oleh penelitian yang dilakukan Sihotang (2006) di Rumah Sakit Umum Doloksanggul yang meneliti hubungan motivasi kerja terhadap kinerja perawat dalam memberikan pelayanan untuk pasien menunjukan ada hubungan signifikan antara motivasi dengan kinerja perawat. Motivasi ditandai dengan munculnya, rasa "feeling", afeksi seseorang.Dalam hal ini motivasi relevan dengan persoalan-persoalan kejiwaan, afeksi dan emosi yang dapat menentukan perubahan tingkah laku manusia. Motivasi akan dirangsang karena adanya tujuan. Jadi motivasi dalam hal ini sebenarnya merupakan respons dari suatu aksi, yakni tujuan. Motivasi memang muncul dari dalam dari diri manusia, tetapi kemunculannya karena terangsang / terdorong oleh adanya unsur lain, dalam hal ini adalah tujuan. Tujuan ini akan menyangkut soal kebutuhan yang akan dicapai oleh orang tersebut.

3. Keterbatasan pene litian

Teknik pengumpulan data pada penelitian ini menggunakan instrument penelitian berupa kuesioner, penggunaan kuesioner ini cenderung bersifat subjektif sehingga kejujuran dari responden menentukan kebenaran dari data yang diberikan, oleh karena itu penelitian selanjutnya diharapkan menggunakan metode penelitian kualitatif dengan metode wawancara mendalam. Keterbatasan dalam penelitian ini antara lain pada saat peneliti melakukan penelitian diruang perawatan dan pada tahap mencari data (penyebaran kuesioner) adanya perawat yang cuti, izin dan sakit sehingga untuk informasi dari yang bersangkutan menunggu sampai masuk kerja kembali dan kesibukan di rawat sehingga menghambat dalam penyelesaian.

\section{Kesimpulan Dan Saran}

\section{Kesimpulan}

Berdasarkan dari tujuan khusus penelitian, hasil penelitian, dan analisis bivariat, maka kesimpulan dari penelitian ini adalah :

Dari 149 responden, sebagian besar responden berjenis kelamin perempuan yaitu sebanyak 91,3\% (136 responden), pada umumnya responden berpendidikan D3 keperawatan yaitu sebanyak $81,9 \%$ (122 responden), dan sebagian besar status perkawinan responden kawin yaitu sebesar 96,6 \% (144 responden). rata-rata umur responden adalah 38,09 tahun dengan standar deviasi 8,170. Usia termuda adalah 26 tahun dan usia tertua adalah 55 tahun. Selanjutnya rata-rata lama kerja adalah 5,79 tahun dengan standar deviasi 2,384, lama kerja terendah 1 tahun dan lama kerja tertinggi 10 tahun. Sebagian besar responden komunikasi baik yaitu sebesar $56,4 \%$ (84 responden), responden terbanyak adalah responden dengan kategori motivasi baik yaitu sebesar $55,0 \% \quad(82$ responden). Dari 149 responden sebagian besar responden kinerja kategori aikyaitu sebesar 56,4\% (84 responden). Hasil uji statistik didapatkan nilai $P$ value $=0,000(\alpha<$ $0,05)$ maka dapat disimpulkan ada hubungan antara komunikasi kepala ruangan dengan kinerja perawat di RS.Hermina Jatinegara. Hasil uji statistik didapatkan nilai $P$ value $=$ $0,001 \quad(\alpha<0,05)$ maka dapat disimpulkan ada hubungan antara motivasi dengan kinerja perawat di RS.Hermina Jatinegara .

2. Saran

a. Bagi Rumah Sakit

Penelitian ini dapat memberikan informasi tentang hubungan komunikasi dengan kinerja perawat, bidang manajemen Rumah Sakit memiliki program untuk meningkatkan kualitas 
pelayanan perawat profesional, dan bekerjasama dengan komite etika dan profesi yang telah ada, diprogramkan dalam program kerja, dan semua perawat Rumah Sakit memiliki ketrampilan komunikasi terapeutik sehingga semua pasien yang mendapatkan perawatan di Rumah Sakit memperoleh kepuasan.

b. Bagi Perawat

Dapat memberikan informasi kepada perawat tentang pentingnya komunikasi terapeutik dalam pelayanan keperawatan dengan pasien Rawat Inap seminggu sekali sebelum

\section{DAFTAR PUSTAKA}

Abdullah, M. A \& Nahla, A. K (2006), Job satisfaction among primary health care physicians and nurses in Al-Munnawarra. The journal of the egyptian public health associations, 81 .

Adams \& Bond, S (2000), Hospital nurse job satisfactions, indoividual \& organizational charachteristic . Jotnal of advanced nursing.

Aditama, T. Y, (2003), Manajemen Administrasi Rumah Sakit, Jakarta : Penerbit UI.

Amos, M. A., Hu, J., \& Herrick, C., (2005), The Impact of Team Building on Communication and Job Satisfaction of Nursing Staff, Journal for Nurses in Staff Development, 21(1), 10-16. Diunduh tanggal 3 Januari 2016.

Arwani \& Supriyatno (2006) Manajemen bangsal keperawatan. Jakarta : EGC

Astuti (2011), Hubungan fungsi pengarahan kepala ruangan dengan kepuasan kerja oerawat di RS Haji Jakarta. Tesis master FIK UI (tidak dipublikasikan)

Awalia, M (2012). Trend dan Issu Pelayanan Kesehatan. http://awalia.or.id/Sta ts/StatCurr.pdf, diakses 3 Januari 2016

Boyle, D. K et.al (2006), Unit type difference in $R N$ workgroup job satisfaction memulai dinas, sehingga para perawat dapat mempraktekkan secara praktis dalam keperawatan setiap hari, untuk membantu kesembuhan pasien Rawat Inap. Serta diharapkan perawat dapat meningkatkan motivasi dalam bekerja karena pengaruh motivasi sangat besar terhadap kinerja.

\section{c. Bagi Peneliti selanjutnya.}

Memberikan acuan atau referensi bagi peneliti selanjutnya yang mengkaji tentang hubungan komunikasi terapeutik dan motivasi perawat dengan kinerja agar dapat melanjutkan penelitian ini dengan pendekatan kualitatif.

, Western Journal of Nursing Research.

Chase, L. K., (2010), Nurse manager competencies. Iowa Research

Online:

http://ir.uiowa.edu/etd/268,

Diunduh tanggal 3 Januari 2016

Degney, H, (2006), Extrinsic And Intrinsic Work Values: Their Impact On Job Satisfaction In Nursing, Journal Of Nursing Management (2006) 14 (4) : 271-281

Damayanthi, Wichaikhum, \& Chontawan, (2014), Predicting Factors of Job Satisfaction among Nurses in Sri Lanka, International Journal of Pharmacy \& Bioscience

Doran, D, et.al (2004), Impact of the Manager's Span of Control on Leadership and Performance, Canadian Health Services Research Foundation, the Canadian Health Services Research Foundation website (www.chrsf.ca). Diunduh tanggal 3 Januari 2016

Feather, R. A. \& Ebright, P. R., (2013). How Staff RNs Perceive Nurse Manager Roles. Journal of Leadership 2013. Vol.2, No.3, 6367. www.dx.doi.org. Diunduh tanggal 3 Januari 2016

Gillies, D. A (1994), Nursing management : A system approach. Philadelphia : W.B saunder Company

Gohari, P. et.al (2012), Relationship Between Rewards And Employee Performance: A Mediating Role 
Of Job Satisfaction, Institute Of Interdisciplinary Business Research 571 July 2013 Vol 5, no 3 www.ijcrb.webs.com. Diunduh tanggal 3 Januari 2016

Gkorezis, P., \& Petridou, E., (2003), The impact of extrinsic rewards on nurses ' psychological, Journal of Economic Aristotle University, Greece. www.joa.au.ac Diunduh tanggal 3 Januari 2016.

Huber, D. L (2006), Leadership and nursing care management, (3-th ed). Philadelphia : Elsevier.

Hastono, S. P (2007), Basic data analysisfor health research training. Analisis data kesehatan. Jakarta:FKM UI

Hafizurrachman, dkk (2010), Beberapa Faktor yang Mempengaruhi Kinerja Perawat dalam Menjalankan Kebijakan Keperawatan di Rumah Sakit Umum Daerah, Journal of Indonesia Medical Association, Volum: 61, Nomor: 10, Oktober 2011, diunduh tanggal 3 Januari 2016

Hachem, F., et.al (2014), The relationships between HCAHPS communication and discharge satisfaction items and hospital readmissions, Patient Experience Journal, Volume 1, www.pxjournal.org, diunduh tanggal 3 Januari 2016

Ilyas, Y (2004), Kinerja, Teori, Penilaian Dan Penelitian. Depok:FKM UI

Ivancevich, Konapske R \& Matteson (2005), Perlaku dan manajemen organisasi (terjemahan Yuwono). Jakarta : Erlangga

Kovner, C, et.al (2006), Factor associated with work satisfactions of registered nurses, Journal of Nursing Scholarship.

Kalisch B. J., Lee. H. \& Rochman, M. (2010), Journal of Nursing Management 18, 938-947 Nursing staff teamwork and job satisfaction, www.nursingmanagement.com. Diunduh tanggal 3 Januari 2016

Kluska, K. M., et.al (2003), Staff Nurse Empowerment Effort-Reward Imbalance, Journal of Nursing Leadership, volume 17 number 1, www.nursingleadership.com. Diunduh tanggal 3 Januari 2016

$\mathrm{Lu}$, et. $\mathrm{Al}$ (2005), Job satisfactions among hospital nurses revisited : a systematic review. Diunduh dari www.sciencedirect.org, diunduh tanggal 4 Januari 2016

Matteson (2005), Manajemen dan prilaku organisasi. Jakarta: Erlangga.

Mangkunegara (2009), Manajemen Sumber daya manusia perusahaan. Bandung : PT Remaja Rosdakarya

Marquish, B. L \& Huston, C. J (2009), Leadership roles and management function in nursing : theory \& application. Philadelphia : Lippincott

Marriner-Tomey \&Alligood (2006). Nursing Theorist and Their Work. Seventh edition.St.Louis: Mosby-Year Book, Inc.

Mayasari, A, (2009), Analisis Pengaruh Persepsi Faktor Manajemen Keperawatan Terhadap Tingkat Kepuasan Kerja Perawat Di Ruang Rawat Inap RSUD Kota Semarang, Tesis (tidak dipublikasikan), Universitas Diponegoro.

Mukarrommah (2010), Hubungan pendidikan dan kinerja dengan kepuasan kerja perawat di ruang rawat inap RSUD Kabupaten Pamekasan. Diunduh dari http://www.fik.umsurabaya.ac.id, diunduh tanggal 3 Januari 2016.

Mundakir (2006) Komunitas Keperawatan Aplikasi dalam Pelayanan. Yokyakarta : Graha Ilmu

Muslim, M, (2010), Tingkat Kepuasan Kerja Perawat Di Ruang Rawat Inap RSUD Pasaman Barat, artikel program Pasca Sarjana KARS Unand (tidak dipublikasikan)

Notoadmodjo (2009), Metodologi penelitian kesehatan. Jakarta : Rhineka Cipta

Nursalam (2011), Manajemen keperawatan : Aplikasi dalam praktik keperawatan profesional. Jakarta : Salemba Medika

Nadzam, D. M, (2009), Nurses' Role in Communication and Patient 
Safety, J Nurs Care Qual Vol. 24,

No. 3, pp. 184-188, Wolters

Kluwer Health Lippincott

Williams \& Wilkins

(www.wkhlww.com). Diunduh tanggal 3 Januari 2016

Peltier, J \& Dahl, A, (2009), The Relationship Between Employee Satisfaction And Hospital Patient Experiences, Journal of Forum Northwestern University.

Peterson, A., (2015), Organizational Support and Job Satisfaction of Frontline Clinical Managers: The Mediating Role of Work Engagement. Electronic Thesis and Dissertation Repository. Paper 2967. www.ir.lib.uwo.ca . Diunduh tanggal 3 Januari 2016

Rampur, S.(2009), Causes of Employee Turnover, Buzzle.com Intelligent life on the web, http://www.buzzle.com/articles/ca uses-of-employee-turnover.html. Diakses pada 4 januari 2016

Ragnadostir, E, D (2013), Influence of nurse unit managers praise on nurses practice, work environment and job satisfaction, Master's thesis in Nursing Management (30 ECTS) at the Faculty of nursing at the University of Iceland, Diunduh tanggal 3 Januari 2016

Robbins, S. P (2006), Perilaku Organisasi, edisi kesepuluh (terjemahan B. Molan), Jakarta : PT Indeks Kelompok Gramedia.

Siahaan, D. N, \& Tarigan, M, (2013), Kinerja Perawat Dalam Pemberian Asuhan Keperawatan Di Rumah Sakit Tk II Putri Hijau Medan, Jurnal Keperawatan Universitas Sumatera Utara (tidak dipublikasikan)

Sitorus, R \& Panjaitan, R (2011), Manajemen keperawatan; manajemen keperawatan di ruang rawat. Jakarta : Sagung Seto

Stamps (1997), Nurses and work satisfactions, an inedx for measurrement (2-nd edition), Chicago : Health Administration Press

Suhasbagyo (2007), Hubungan gaya kepemimpinan dan struktur organisasi rumah sakit pelabuhan Cirebon terhadap kepuasan kerja perawat dan bidan, http://arc.ugm.ac.id/files/abst_(39 46-H-2007).pdf

Swansburg, R. C (2000), Pengantar kepemimpinan dan manajemen keperawatan untuk perawat klinis (alih bahasa S Samba), Jakarta : EGC

Tantri, B. D \& Kembaren, E. M, (2005), Hubungan antara dimensi dimensi gaya kepemimpinan kepala perawat dengan motivasi berprestasi di sebuah rumah sakit. http://lib.atmajaya.ac.id, (tesis tidak dipublikasikan). Diakses tanggal 4 Januari 2016.

Tappen, R.M, Weiss, S. A \& whitehead, D. K (2004), Essential of nursing leadership and management (3 ed). Phioladelphia : F. A Davis Company

Wahyuni, S (2007), Analisis Kompetensi Kepala Ruang Dalam Pelaksanaan Standar Manajemen Pelayanan Keperawatan Dan Pengaruhnya Terhadap Kinerja Perawat Dalam Mengimplementasikan Model Praktik Keperawatan Profesional Di Instalasi Rawat Inap RSUD Banjarnegara, Master Thesis Pasca Sarjana Keperawatan Universitas Diponegoro. Diunduh tanggal 3 Januari 2016

Wibowo (2007), Manajemen kinerja, (Edisi pertama), Jakarta : PT Raja Gravindo

Wijono, S. (2010), Psikologi industri dan organisasi; dalam satu bidang gerak psikologi sumber daya manusia, Jakarta : Kencana. 